\title{
Political Commitment Analysis in the Tuberculosis (TB) Treatment Program
}

\author{
Dwi Sapta Aryantiningsih, Muhammad Giatman, Novi Yanti
}

\begin{abstract}
Tuberculosis or TB is an infectious disease in public health. The case-finding rate in Riau was only $39 \%$ and Pekanbaru only $37.5 \%$. This objective is to analyze the political commitment of regional leaders in the effort to control TB. This research was qualitative, subjects were 1 manager in the Health office, 1 staff, 2 managers of Public Health Centre. Data collection was carried out by interview and document study. The results show there is political commitment related to the $T B$ program, recording and reporting standards with the SITB, a program plan is drawn up every year, such as human resources, budget, facilities and infrastructure, and involving the community. The conclusion is the political commitment of the leadership in TB is quite good but it is suggested to increase in the allocation of funding, human resources must consider.

Keywords: commitment, leadership, tuberculosis.
\end{abstract}

\section{INTRODUCTION}

$\mathrm{T}_{\mathrm{B}}$ B is ten infectious diseases that can cause death. Therefore, it is necessary to take through effective and efficient prevention, control and eradication efforts. TB is caused by Mycobacterium tuberculosis. This disease is a spread rapidly who people who are vulnerable and have a weak immune system. It is estimated sufferers with tuberculosis who are TB bacteria in sputum or BTA $(+)$, it will infect to 1 until 10 patients [1]. Once the cough can produce about 3,000 droplets containing germs contained as many as 0-3500 if sneezes contain germs Mycobacterium tuberculosis until 4,500-1,000,000 [2].

Globally, there are an estimated 1.2 million deaths from TB. Geographically, the highest TB cases occurred in Southeast Asia (44\%) followed by Africa (24\%). The countries that account for two-thirds of TB cases in the world were India (27\%), China (9\%), Indonesia (8\%) [3]. There were 98,000 deaths (including 5300 deaths in people with HIV). TB treatment coverage was $67 \%$ and the treatment success rate was $85 \%$, it was still below target at $90 \%$ on

Manuscript received on February 08, 2021.

Revised Manuscript received on March 30, 2021.

Manuscript published on March 30, 2021.

* Correspondence Author

Dwi Sapta Aryantiningsih*, Doctoral Student of Technology and Vocational Education, Universitas Negeri Padang - Indonesia and Lecturer of the Study Program of Public Health, STIKes Payung Negeri Pekanbaru Indonesia. Email: dwisapta.aryantiningaih@payungnegeri.ac.id

Muhammad Giatman, Senior lecturers/professors of Technology and Vocational Education, Universitas Negeri Padang - Indonesia.: giatman@ft.unp.ac.id

Novi Yanti, Lecturer of the Study Program of Public Health, STIKes Payung Negeri Pekanbaru - Indonesia. Email: novi_yanti7803@yahoo.com

(c) The Authors. Published by Blue Eyes Intelligence Engineering and Sciences Publication (BEIESP). This is an open access article under the CC BY-NC-ND license (http://creativecommons.org/licenses/by-nc-nd/4.0/)
2022 [4].

Detection cases in Riau were 39\%, notification rate of all cases 154 in 100,000 population, the success rate of treatment 87.5\% national target is $85 \%$ [5]. In Pekanbaru, the number of deaths was 39 people, the case detection rate was $37.5 \%$, the number of cases was 3242 people, the case notification rate was 284 per 100.0000 population, the cure rate was $59.9 \%$, the complete treatment rate was $69.5 \%$ and the treatment success rate was $92.3 \%$ [6]. Therefore, it is necessary to take a serious effort to manage TB disease. The point of Directly Observed Treatment Shortcourse that reinforcement political commitment of program leadership for elimination is in 2035 [7].

The commitment of leadership necessary for decision-making is done properly and the output quality that is produced [8]. The TB program's leadership must make the TB program as a top priority, with planning and financial support, human resources and promotion by involving the community and community organizations.

\section{METHODS}

This study used a qualitative approach, is aimed to discover the political commitment of the TB program in Pekanbaru Health office. This research was conducted from April to July 2020. The subject were1 manager program in the Health office, 1 staff program, 2 managers Public Health Centre. Data collection techniques used in-depth interviews, document review.

\section{RESULTS AND DISCUSSION}

\section{A. Results}

The political commitment strategy on TB includes policies, standards, recording and reporting, planning, recruitment resources personnel, budget, facilities and infrastructure, promotion by involving the community. Following are excerpts from interviews with TB manager program at the Health Office:

"The role of the Pekanbaru Health Department is as a supervisor and supervisor for health facilities that implemented the DOTS program that has been established by the Center. If I'm not mistaken, Regulation No. 67/2016. The TB program is very important. Transmission of tuberculosis is very easy, the mortality rate was very high and $T B$ is the national program".

Published By:

Blue Eyes Intelligence Engineering \& Sciences Publication

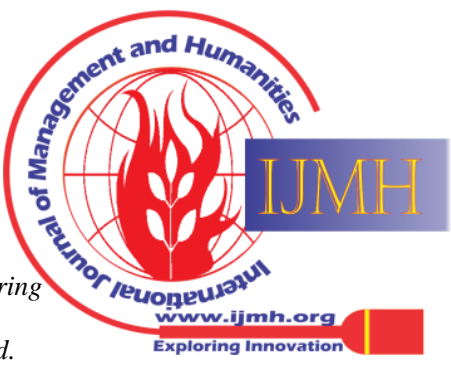


From the document review, it is known that the implementation of the TB program in Pekanbaru Health Department refers to TB guidelines issued by the Ministry of Health. The part of DOTS is the political commitment of the leadership program, it includes support for administration, operations, human resources must be met like their training.

From the aspect of recording and reporting, it refers to the predetermined standards. The results of interviews with staff program are as follows: "Mmm...For recording and reporting using existing forms. For example TB form 01 for TB treatment cards...there are many forms. Now up to TB 16 but in public Health Centre TB 1 to 6 plus 9, 10".

Following from interviews with TB manager program at the Health Office: "Starting in 2020, recording and reporting use an information system called SITB (Tuberculosis information system). Under 2019 using SITT. There is also a manual using forms...TB forms 01-16. At Department of Health, fill out the TB forms 7,8, 11 to $16^{\prime \prime}$.

From the document review, it was found that TB was recorded and reported using TB formulir 01-16 and Tuberculosis information system. In the case of a planning program, the supervisor will plan the program for the next year and submit it to the Regional Development Planning Agency. The results of the interview with Manager program in Department are as follows: "Eeee. TB program planning was prepared in the previous year. Then it submitted to the Government. But sometimes there is a budget adjustment if the submission is outside the ceiling. So we have to revise the program".

From the document review, it is found that the budget and expenditure plan documents have been approved by the leaders. Availability of resources includes human resources, budget, facilities and infrastructure at the Department of Health, there only has 1program supervisor, 1 program staff at the Primary Health Care there are 53 general practitioners, 1 program leader, 260 laboratory experts in all Primary Health Care and Hospitals.

The results of the interview with Manager program in Department are as follows: "Health facilities have MoU with Department of Health, where the requirements in this DOTS are doctors. Nurses. Analysts. Pharmaceuticals. Medical records. And then government and private hospital. Primary Health Care is 21 and clinic 72".

From the document review, it was found that a list of the number of health personnel in health who was in the TB booth program. The coordination between programs and sectors involving community organizations, it has been successful, but not yet effective.

The results of the interview with the manager program in Department are as follows: "The coordination sector is good. .MoU with another facility of Health, we have MoU with Primary Health Care, government and private hospitals, and clinics too".

The results of the interview with manager program in Public Health Centre are as follows: "Cooperation is also with NGO like PKBI (LKNU) which mobilizes TB community in Pekanbaru City and there is also KOPI TB".

\section{B. Discussions}

The leadership politic commitment is needed. Commitment is defined as a work attitude that reflects the alignments or involvement of individuals in the organization. It is shown with their willingness to be steady, firm attitude

and serious in doing something. With this commitment, the leadership will act and be responsible for the decisions that have been taken [9]. In organizations, leadership is used to influence subordinates to carry out something as expected [10]. Effective leadership is essential for success and coordination. The leadership's skill is needed in taking steps in term funding and cross-sectoral cooperation [11].

In Indonesia, the TB program is a top priority. The duty Department of Health as a supervisor and coach of primary health care and hospital. TB programs carried out by health workers at first-level health facilities or hospitals should follow the Minister of Health Regulation. In Korea, the goal is to increase human resources who understand the objectives of the TB program, strategic planning and policies [12]. In recording and reporting using the Tuberculosis Information System (SITB) to replace the Integrated Tuberculosis Information System (SITT). The guidance and instruction filling formulir done by a supervisor, but implementation, there is still a postpone of delivery in reporting because of responsibilities in other programs.

[13] research shows that recording and reporting system using a systematic and thorough standard register it will facilitate the assessment of program activities. Furthermore, there is the preparation of a program plan for the next year. Based on the results of [14], it indicates that the availability of funds is an important factor so that the program can run optimally. In improving the quality of human resources, training can be fulfilled. To improve the quality of human resources, with education so that human resources competencies will be increased [15]. For health program leader, the improving management competencies are conducted through the training program. In every primary health care and hospital, there is also a general practitioner, however, the number is still insufficient. For the leader of the program, only one person is in the primary health care or Hospital and has duties and responsibilities in managing other programs. This adds to the workload.

The collaboration with the Association of Indonesian Family Planning and health society which in the community development of health has been accomplished. [16] need their commitment and cooperation for mutual coordination called the whole of government for the prevention and control of tuberculosis. [17] research asserted that the government's commitment to involving shareholders and cross-sectoral policies is necessary. Also, there is a need for collaboration from related sectors to achieve optimal treatment [18-23].

\section{CONCLUSION}

Political commitment in the TB control program included policies related to the TB program of a Minister of Health Regulation, the existence of recording and reporting standards with SITB forms and information systems, the implementation of program planning every year, the provision of human resources, budget, facilities and infrastructure and promotion was undertaken by involving the community and community organizations.
Published By:

Blue Eyes Intelligence Engineering \& Sciences Publication

(C) Copyright: All rights reserved.

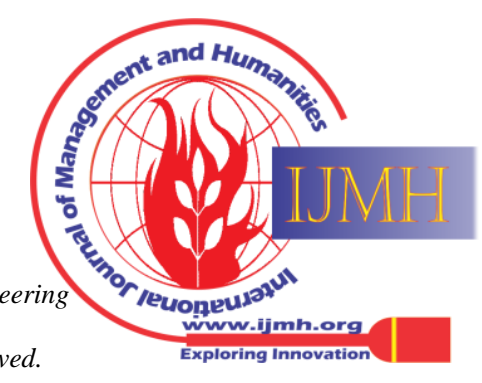




\section{ACKNOWLEDGMENT}

In this study, the research would like to thank the help of all participant, especially the Head of STIKes Payung Negeri Pekanbaru, the leader of TB Program at the Department of Health and Primary Health Care.

\section{REFERENCES}

1. S. Suryatin, R. Anugerah, N. Indrawati. Pengaruh sumber daya manusia, ketersediaan infrastruktur, komitmen pimpinan, dan keteladanan pimpinan terhadap tingkat maturitas sistem pengendalian intern pemerintah (Studi pada Pemerintah Daerah Kabupaten Indragiri Hulu). Pekbis. Jurnal Pendidikan Ekonomi Dan Bisnis, 11(1). 2019

2. S. Oktavia, R Mutahar, S. Destriatania. Analisis faktor risiko kejadian TB Paru di wilayah Kerja Puskesmas Kertapati Palembang. Jurnal Ilmu Kesehatan Masyarakat. 2016, 7(2).

3. WHO. TB Report. WHO Library Cataloguing-in-Publication Data World, 7. Retrieved from https://w. ww.who.int/tb/publications/global_report/tb19_Exec_Sum_12Nov2019 .pdf?ua=1 (2019a).

4. WHO. Global Tuberculosis report country profile 2019. Publication, 63(10), (2019b). pp. 476.

5. Kementrian kesehatan. Profil Kesehatan Indonesia 2019. Kementerian Kesehatan RI.

6. Dinas Kesehatan. Profil Dinas Kesehatan Kota Pekanbaru Tahun 2019.

7. Kementrian Kesehatan. Peraturan Menteri Kesehatan RI Nomor 67 Tahun 2016 Tentang Penanggulangan Tuberkulosis.

8. Kementrian kesehatan. Kebijakan Program Penanggulangan Tuberkulosis Indonesia. Modul Pencegahan Dan Pengendalian Penyakit. 2017.

9. M. Priyono. Manajemen Sumber Daya Manusia. Zifatama Publisher. Sidoarjo. 2008.

10. M. J. Lubis, I. Jaya. Komitmen Membangun Pendidikan (Tinjauan Krisis Hingga Perbaikan Menurut Teori). 2019.

11. A. Tanjung. Influence of Leadership Orientation and Level of Awards Against Employee Loyalty in Lancang Kuning University, 2(6), 2020, pp. 412-421.

12. M. J. A. Reid, E. Goosby. Improving quality is necessary to building a TB-free world: Lancet Commission on Tuberculosis. Journal of Clinical Tuberculosis and Other Mycobacterial Diseases, 2020. 19, pp. 100156.

13. U. Go, M. Park, U N. Kim, S. Lee, S. Han, J. Lee. Tuberculosis prevention and care in Korea: evolution of policy and practice. Journal of clinical tuberculosis and other mycobacterial diseases, 2018, 11, pp 28-36.

14. J. R. A Tangkilisan, F. L. F. G Langi. Angka Penemuan Kasus Tuberkulosis Paru Di Indonesia Tahun 2015- 2018. 2020.

15. E. Aryani, H. Maryati. Analisis Pelaksanaan Penanggulangan TB Paru di Wilayah Kerja Puskesmas Cipaku Tahun 2017. HEARTY: Jurnal Kesehatan Masyarakat, 6(1). 2018.

16. Suparno. Relevansi perkuliahan fabrikasi logam dengan tugas mengajar guru di smk negeri sumatera barat. Pakar Pendidikan, 14(2), 2016, pp. 73-86.

17. P. Dinsdale. Whole government approach is needed to improve health across Europe, says WHO. BMJ (Cliinical Research), (343) 2011.

18. M. Engelina. Analisis Penatalaksanaan Program Penanggulangan TB Paru dengan Strategi Dots di Puskesmas Belawan Kecamatan Medan Belawan Tahun 2017. Sumatera Utara. 2018.

19. R. Melyanti. Aplikasi Pengelolaan Keberangkatan Penumpang pada PT. Indah Travel. Jurnal Ilmu Komputer, 7(1), 2018, pp 15-21.

20. R. Melyanti, M. Iqbal. Sistem Informasi Manajemen Penelitian Dan Pengabdian Masyarakat Di Bagian P3m (Studi Kasus: Stmik Hang Tuah Pekanbaru). Jurnal Ilmu Komputer, 9(2), 2020, pp. 165-176.

21. R. Melyanti R, Y. Andreas. Sistem E-wisata pada Dinas Pariwisata di Kota Pekanbaru Berbasis Android. Jurnal Ilmu Komputer, 6(2), 2017, pp. 124-127.

22. H. Hidayati, Suhardi, D. Irfan, A. Ambiyar, R. Melyanti. Sistem Informasi Pelanggaran Siswa Berbasis Web Menggunakan Rapid Application Development. INTECOMS: Journal of Information Technology and Computer Science, 3(2), 2020, pp. 234-242.

\section{AUTHORS PROFILE}

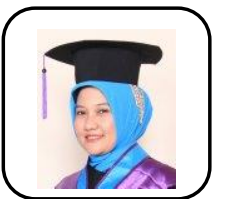

Dwi Sapta Aryantiningsih, is a Doctoral Student of Technology and Vocational Education, Universitas Negeri Padang - Indonesia and Lecturer of the Study Program of Public Health, STIKes Payung Negeri Pekanbaru - Indonesia.

Published By: Blue Eyes Intelligence Engineerin \& Sciences Publication
Tut Technology and Vocational Education, Univis Negeri Padang - Indonesia.

Novi Yanti, is a Lecturer of the Study Program of Public Health, STIKes Payung Negeri Pekanbaru Indonesia 